\title{
Editing Chaucer's Early Poems: A Rationale for Virtual Copy-Text
}

\section{Murray McGillivray}

The particular conception of copy-text proposed by W. W. Greg in his "A Rationale of Copy-Text," especially his "distinction between the [...] 'substantive' [...] readings of the text, those namely that affect the author's meaning or the essence of his expression, and others, such in general as spelling, punctuation, word division, and the like, affecting mainly its formal presentation, which [...] I shall call [...] 'accidentals," " has not really achieved much purchase in the field of editing medieval vernacular manuscript texts, perhaps because punctuation is often entirely or largely missing in them, word division purely scribal, and spelling subject to dialect translation from manuscript to manuscript. Nevertheless, the general procedure that Greg recommended - briefly, that "copy-text should govern (generally) in the matter of accidentals" 2 - is the one that holds sway in the editing of medieval text though under different terminology: the usual procedure is to select one manuscript, if there are several, as the 'base text' for an edition and to emend its text (if at all) only in cases of substantive disagreement with other manuscripts (if a better reading exposes an error in the base manuscript) or when there is obvious error shared by all manuscripts.

This procedure serves very well in cases where there are good early manuscripts, but the results are not as happy when all of the manuscripts of a work are late and flawed. Such is the case with many of Geoffrey Chaucer's earliest works. Editors of

1 Greg, "Rationale," 21.

2 Greg, "Rationale," 26. 
Chaucer's Canterbury Tales face important difficulties, including the sheer number of manuscripts to consider and the frequent lack of clear or consistent genetic relationships between these manuscripts. Editors of Chaucer's earlier poetry do not have these problems. In dealing with the Book of the Duchess, Anelida and Arcite, the House of Fame, the Parliament of Fowls, and the Legend of Good Women (the group of texts with which this paper is concerned, with a particular focus on the Book of the Duchess), editors find themselves looking at too few manuscripts rather than too many. They find themselves dealing with groups of manuscripts which are so closely related to one another that errors common to the entire tradition are likely rather than merely possible.

The textual situations of these five poems are strikingly similar: they are preserved principally or only in a few late manuscripts, including Fairfax 16 and its near relative Bodley 638 (quite generally of no independent help), Tanner 346, Pepys 2006, Longleat 258, and Digby 181. Only the Parliament of Fowls and the Legend of Good Women are preserved in a manuscript dating much less than half a century after the death of Chaucer. These two poems are included in the earliest known anthology of Chaucer's poetry, Cambridge University Library MS Gg 4.27, produced about 1420. They may have been available to the editors of this manuscript in the form of separate booklets, and in general the evidence may point to independent and limited circulation of the five poems in separate booklets before a fifteenth-century episode of collection, re-edition, and release to the scrivener and bookshop trade, an episode which resulted directly or indirectly in such anthologies as Fairfax 16 and Tanner 346 (both c.1450, with Tanner earlier) as well as Pepys 2006 (c.1450-1475).

The evidentiary situation is particularly dire for the Book of the Duchess, which is represented only in Fairfax 16, Bodley 638, and Tanner 346, and for the House of Fame, which is preserved only in Fairfax 16, Bodley 638, and Pepys 2006. Readers are often unaware how precarious the texts of these poems are. Since in both cases the Bodley text is closely related to the Fairfax text, there are in effect only two witnesses to each poem, Fairfax and Tanner for the Book of the Duchess and Fairfax and Pepys for the House of Fame. Nor are they particularly good witnesses. The Fairfax/Bodley tradition is often erroneous either through misreading and misunderstanding or through attempts at improvement, as the control of another manuscript makes it possible to detect, and the scribes appear to have had no firm sense of Chaucer's metre. As for Tanner, its scribes adopt wholly un-Chaucerian spelling systems in complete ignorance of his metre, while the scribe of Pepys for the House of Fame is "Careless of 
inflection and metre, with many small omissions and insertions."3 Moreover, in the case of the Book of the Duchess, the archetype from which all of the surviving versions derive is known to have been flawed, so all of the extant manuscripts share flaws of greater or lesser extent, including a textual gap of what must be some dozens of lines which occurs early in the poem in all manuscript versions, filled with lines 31-96 in Thynne's edition. (The abrupt ending of the House of Fame might also indicate a seriously flawed archetype, though most describe the work as unfinished.)

As a result of these difficulties, modern editors of these two poems have adopted a conservatism that verges on timidity, taking Fairfax 16 as their base manuscript and emending only when absolutely necessary to produce adequate sense and generally with reference to the other manuscripts, despite the fact that Fairfax has, as F. N. Robinson noted, "peculiarities" of spelling and forms "inconsistent with Chaucer's usage" and "readings [...] unsatisfactory in sense." 4 The reasons for this choice are both practical and theoretical. On the one hand, there is the counsel of desperation: there appeared to be no practical alternative to choosing the so-called best manuscript and working from it, even when that manuscript is rather bad. On the other hand, the second half of the twentieth century was a period when a profound distrust of critical editing dominated for what seemed to be sound theoretical reasons. What had been a posture of conservative editing in the first half of the century, a willingness to concede the possibility that close attention to the text presented by actual medieval manuscripts rather than to the intuitions of the modern editor would bring surer results, gradually morphed into a feeling of incapacity when faced with variant readings in manuscripts: how could we moderns presume to choose one reading over another? Best-text editing prospered; the few remaining scholars using critical methodologies, such as George Kane and E. Talbot Donaldson, found themselves tarred with the same brush as W. W. Skeat as mere inventors of the texts they claimed to reveal. In this climate, the New Philology of the late 1980s came as a godsend and indeed as an apotheosis of the anti-critical spirit of the times. There are only, really, the manuscripts themselves to attend to; any invented text supposed to pre-date them is purely the product of modern imagination and no fit object for study by medievalists. ${ }^{5}$

In the case of the Canterbury Tales, this sort of attitude could make a reasonably happy marriage with the existing texts. Two very early Canterbury Tales manuscripts

3 Seymour, A Catalogue of Chaucer Manuscripts, 1:92.

4 Robinson, ed., The Works of Geoffrey Chaucer, 2nd ed., 899, 898.

5 Cerquiglini, Éloge de la variante, 33-54. 
by the same scribe exist, Hengwrt and Ellesmere, both of which are very good, though Hengwrt is not nearly as good as the immediate post-Pinkhurst buzz suggested. ${ }^{6}$ But despite its gaps and errors, it is an excellent, early, apparently largely unedited witness to the Canterbury Tales and, in that sense, the best possible manuscript. So when the Variorum Chaucer editors chose a "modestly emended or corrected" Hengwrt as their base text, ${ }^{7}$ this choice, although it appeared radical at the time, was quite sound, despite the end-of-civilization-as-we-know-it imprecations of John H. Fisher. ${ }^{8}$ Likewise, Ellesmere, though currently not basking in as warm a glow of purported authorial involvement, is carefully edited and arranged, very early and likewise close to authorial papers, and thus in another sense the best manuscript.

Editors of Chaucer's early poems have no such manuscripts to place confidence in. Fairfax 16, the common choice of base text, is speciously attractive. This is true in the medieval sense of the word speciosus - Fairfax 16 is a clear, lovely manuscript but also in the modern sense: although its readings are often plausible, those of other manuscripts often hold up better to scrutiny. Tanner 346 often has superior readings, but, though earlier than Fairfax, has been neglected by editors until very recently, probably because of its odd un-Chaucerian spelling, ugly utilitarian look and feel, and water-damaged sections. To give one example, in the Fairfax-based Benson edition of the Book of the Duchess, lines 1003-5 read, "That Trouthe hymself over al and al / Had chose hys maner principal / In hir that was his restyng place,"9 where the Tanner reading "had closed" is clearly preferable. ${ }^{10}$ And Fairfax itself also has un-Chaucerian spelling. There may be enough similarity between its spelling system and that of the best Canterbury Tales manuscripts to pass the scrutiny of student readers of the Benson edition but, as Robinson had already noted, not to pass the test of careful study.

6 My reference is to online and in-person comments, principally by Chaucerians who are not textual scholars, in the years immediately following the bombshell oral presentation by Linne Mooney of her identification of the scribe of Hengwrt at the 2004 New Chaucer Society meeting in Glasgow (later published as "Chaucer's Scribe"), comments which often revealed a completely unjustified new trust in the Hengwrt text of the Canterbury Tales and which several of the presentations by textual scholars at the 2006 meeting of the Society in New York strove to deflate.

7 Ruggiers, "Editor's Preface," in the Variorum Chaucer Facsimile of the Hengwrt Manuscript, xii.

8 Fisher, "Animadversions."

9 Benson et al., eds., The Riverside Chaucer.

10 See the Middle English Dictionary s.v. "closen," sense 4a "To fortify (a city, castle, etc.) by surrounding it with a wall and/or a moat." The neglected Tanner reading alone provides a coherent image in this line and the next, in which Truth first builds his castle and then dwells there. 
In fact, there is no sound choice of copy-text for an edition of the Book of the Duchess, the House of Fame, or Anelida and Arcite at all, and the situation is only marginally better for the Parliament of Fowls and the Legend of Good Women.

A possible way forward for the editor was, to my knowledge, first suggested by M. L. Samuels in his 1983 article on "Chaucer's Spelling": at the end of that article, Samuels points out that if editors want the best approximation of Chaucer's own language, they "have the choice of adopting the spellings of Hengwrt as they stand, or of modifying them in the direction of those of the Equatorie." 11 Although Chaucer's relationship to the Equatorie of the Planetis has not been agreed upon and although aspects of Samuels's account of Chaucer's spelling have been cogently critiqued by subsequent scholarship including that especially by Simon Horobin, ${ }^{12}$ even Horobin describes Hengwrt as "the best evidence we have for Chaucer's language." ${ }^{13}$ Indeed, Hengwrt's credibility as a witness to the Chaucerian text has only increased in recent years, particularly as a result of Linne Mooney's identification of the Hengwrt/ Ellesmere scribe, formerly known as Scribe B following A. I. Doyle and M. B. Parkes, ${ }^{14}$ as one Adam Pinkhurst and "very probably" the same Adam as Adam Scriveyn and therefore someone who had written out Chaucer's Canterbury Tales "possibly under his supervision." 15

It is not entirely clear, however, what Samuels was proposing when he spoke of "adopting the spellings of Hengwrt" or when he suggested "modifying them in the direction of those of the Equatorie," a work that provides spellings for no more than a tiny fraction of the vocabulary of the Canterbury Tales, let alone the whole Chaucerian ouvre. Since the modification of spellings "in the direction of those of the Equatorie" could never have been a genuine project (despite being taken seriously enough by Larry D. Benson to formulate a printed objection ${ }^{16}$ ), perhaps all he had in mind was the selection of Hengwrt spellings for the Canterbury Tales themselves in those cases where they differ from Ellesmere spellings. But Janet Cowen and George Kane appear to have taken Samuels to be advocating the imposition of the Hengwrt standard of spelling (insofar as the spellings of Hengwrt constitute a standard) on works

11 Samuels, "Chaucer's Spelling," 37.

12 See especially Horobin, "A New Approach to Chaucer's Spelling."

13 Horobin, "The Language of the Hengwrt Chaucer."

14 Doyle and Parkes, "The Production of Copies," 170.

15 Mooney, "Chaucer's Scribe," 97-138 at 101 and 97.

16 Benson, "Chaucer's Spelling Reconsidered." 
other than the Canterbury Tales, pointing out that "to rewrite the poem [the Legend of Good Women] in the language presumed to be Chaucer's," a step they do not take or advocate, is "knowledgeably discussed by Samuels, 1983."17

Whether the idea is in fact Samuels's or belongs to Cowen and Kane's interpretation of his article, such a rewriting was actually proposed by M. C. Seymour, first in the 1995 first volume of his Catalogue of Chaucer Manuscripts, and then in a more extensively in a recent article. ${ }^{18}$ He proposes that an edition of the Book of the Duchess as

a reconstruction of the poem in the language of the Hengwrt manuscript of the Canterbury Tales (the nearest we have to Chaucer's language) would illuminate and perhaps solve some of the metrical unevenness, and a rethinking of some traditional defences of odd readings may remove some scribal simplification and modernization and recover older readings. ${ }^{19}$

This approach has substantial and obvious dangers and difficulties, both theoretical and practical, of course, and four principal objections occur immediately. First, as Seymour himself admits, Chaucer's language of the early 1370s may well have differed in greater or lesser particularities from his language of the mid to late 1390 s. $^{20}$ Second, the resulting text will certainly be open to the easy charge of being a modern confection that never existed as such in the Middle Ages. Third, the criteria for choosing a base text to re-spell, and particularly the criteria for emendation and improvement of the re-spelled result are difficult to conceive. Finally, the methodology of re-spelling the text of one manuscript so as to produce a new version of it using the spellings imported from an entirely different poem is not at all easy to grasp in practical terms.

The first and second of these objections are genuine and theoretically valid, of course, though the second applies, mutatis mutandis, to any modern edition of a medieval work, and the easy though admittedly not completely satisfactory answer to the first is that Chaucer's own language of the 1390s (to the extent that it really is represented by such a good early manuscript of his Canterbury Tales as Hengwrt) is more likely to resemble Chaucer's own language of the 1370s than are the usages, spellings, and grammars imposed on his early works by scribes working late in the first half of the following century, some seventy or eighty years after the composition

17 Cowen and Kane, eds., Geoffrey Chaucer: The Legend of Good Women, 149 and 149 n.16

18 Seymour, "Chaucer's Book of the Duchess."

19 Seymour, A Catalogue of Chaucer Manuscripts, 1:2.

20 Seymour, "Chaucer's Book of the Duchess," 68. 
of the Book of the Duchess. The methodological objections, third and fourth above, are best met by finding reasonable procedures rather than by argument, and the remainder of this article describes the procedures which M. C. Seymour and I are adopting in carrying out his proposal. But the real answer to the host of objections which could be raised against our procedure or our goal is that what we propose is a critical edition of the Book of the Duchess undertaken as an experiment with new techniques, simply to see what these approaches might yield.

This proposal does offer, we believe, a way past the methodological impasse that has particularly affected editors of Chaucer's early poems, as described above. It is also consistent with the role which, I believe, critical editing will have as we move into the twenty-first century. As I have argued elsewhere, the critical edition was trapped from its inception by the technology of print and paper into a dual role that created diametrically opposed demands. ${ }^{21}$ On the one hand, a critical edition aimed to offer a theory of the text, its original state, and the changes wrought in transmission, a theory elaborated in terms of the text itself, which meant that this is a goal that necessarily involved alteration of the text as preserved in manuscripts. On the other hand, the goal was to make public the textual evidence that survived in the manuscripts, and from this point of view, as little alteration of the surviving manuscript texts as possible was desirable. This latter goal, under the general heading of fidelity to the base of evidence, gradually won out over the former in the course of the twentieth century because print and paper technology and the economics of that technology meant that there was almost never room to present both a theory of the text and the full evidence from which the theory arose. However, digital technology now makes the full presentation of the evidentiary base much easier, and this should allow the critical edition to liberate itself from the bind of the dual role described above and to devote itself solely to expressing text-theories. In this environment, there is no obligation to reach textual certainty, but there is much freedom to explore different theories of the text: "providing the full texts of all witnesses would change the status of the critical edition; since its theoretical and conjectural nature would be openly seen, the critical edition itself could afford to take greater risks." 22 I have called this

21 McGillivray, "Towards a Post-Critical Edition.”

22 McGillivray, "Towards a Post-Critical Edition," 188. In the main, this opportunity has not yet been seized by practitioners of the digital edition, perhaps because their attention has been focused instead on struggling with the practicalities of the new medium - this, in any case, accounts for my own conservatism in the 'critical text' (really a reconstructed archetype, as the introductory material makes clear) of the hypertext Book of the Duchess. 
combination of open-archive provision of the evidentiary base and the resulting creative liberty of the text-theorist "post-critical."

Even creative liberty needs rules and methods, however, if the result is not to be a mere pastiche. We have adopted the following procedures. First, relying entirely on the evidence of the surviving manuscript versions, I have reconstructed the archetype from which those manuscript versions derive. Since the scribal or editorial agenda of Fairfax 16 is clearly recuperative and completive and includes a series of emendations designed to compensate for a failure to understand the metricality of final $-e,{ }^{23}$ I have based the reconstructed archetype closely on Tanner 346, both because of its apparently slightly earlier date and because of the relative infrequency of any editorial interference in its text. The reconstruction is limited to substantive readings and without reference to what Greg called "accidentals," 24 and the spelling of the reconstructed archetype is therefore, in the main, the very un-Chaucerian spelling of Tanner. ${ }^{25}$ (For lines 31-96, not certainly genuine and not present in any of the manuscripts except Fairfax, where they are copied from a printed edition in a late hand, we are forced to use Thynne's edition as if it constituted the archetype.) The procedure to this point is exactly the reverse of that recommended by Greg: rather than adopting the accidentals of a copy-text, we work towards a virtual copy-text by following substantive readings to an archetypal text whose accidentals are bound to be unauthorial in many places. The rather unfamiliar spelling systems of Tanner are not a concern at this stage, since spelling is not an issue until the next step. It is also worth noting that this reconstruction does not take us very far in 'substantive' terms. The manuscripts we are using, Fairfax, Bodley, and Tanner, are very closely related in the stemmas of Anelida and Arcite, the Parliament of Fowls, and the Legend of Good Women, and they omit lines at the same places and have what can only be erroneous readings in common. They probably all derive at no very great distance from a single booktrade copy of the poem of about 1430 .

The second stage is to replace the spellings of the reconstructed archetype with spellings taken from Hengwrt. To do this, I have constructed a digital concordance of Hengwrt words using (with permission) an unpublished digital transcription of Hengwrt prepared at the University of Toronto in the late 1980s by Ian Lancashire and

23 See Cowen and Kane, eds., Geoffrey Chaucer: The Legend of Good Women, 145-49.

24 Greg, "Rationale," 21.

25 In the main, the reconstructed archetype follows the reconstruction proposed in McGillivray, Geoffrey Chaucer's 'Book of the Duchess': A Hypertext Edition. 
applying R. J. C. Watt's Concordance programme, and then I have combed manually through the text of the Book of the Duchess using the programme to look for the Hengwrt spelling of each word. We have also been assisted by the Hengwrt Chaucer Digital Facsimile and the printed concordance of Norman Blake's edition, which is based on Hengwrt. ${ }^{26}$ This is not a mechanical exercise, because there does not exist any fuzzy search mechanism broad enough to find Tanner words in Hengwrt despite the different spelling systems and still narrow enough to give only a few results. In the many cases where Hengwrt offers two (or sometimes more) spelling variants, I routinely chose the most common Hengwrt spelling, except in those cases where Hengwrt's own spelling system deploys spelling variants with apparent intent; for example, the past participles and past tense forms of regular verbs are usually methodically differentiated by spelling in Hengwrt.

Of course, there is a residue of words used in the Book of the Duchess but not in Hengwrt, including classical names and, most prominently, chess terminology and hunting terms, and since we take the Tanner manuscript forms to be rather unreliable, we had to develop a method of dealing with these cases. I looked first for analogies within Hengwrt forms, for example, words with the same root, words with the same suffix, and so on. All such searches are easily done using wildcards in Watt's Concordance programme. Secondly, I looked for instances in Chaucer's other poetry, particularly poems that have good early manuscripts, such as the Corpus Christi College manuscript of the Troilus, and, for words found in the Canterbury Tales but not in Hengwrt, the Ellesmere manuscript of the Tales. About $97 \%$ of the words in the Book of the Duchess also occur in the Hengwrt manuscript of the Canterbury Tales; thus, in only a few cases was I forced into a position of choosing arbitrarily between variants offered by the Book of the Duchess tradition itself, and in these cases I examined as widely as I could the corpus of Middle English as it is reflected in the entries of the Middle English Dictionary to attempt to discern what the late-fourteenth-century London variant would have been.

A brief sample of the reconstructed archetype (left column) and the re-spelled text follows, including notes drawing attention to some of the kinds of problems the process encountered:

and as I lay pus wondir loude me pouzt I herd a hunte blowe tassai his horne \& forto knowe
And as I lay thus wonder loude Me thoughte I herde a hunte blowe Tassaye his horn and for to knowe

26 Blake et al., eds., A New Concordance. 
whepir it were clere or hors of soune and I herd goyng bop up \& doune men hors hondis \& oper ping and al men spake of hontyng hou pei would sle pe hert wip strengthe
Wheither it were clere or hoors of soun, And I herde goynge bothe vp and doun Men hors houndes and othere thyng And al men spak of huntyng

How they wolde sle the hert with strengthe

345 herde: $47 \times$ vs. 'herd' $59 \times$; 'herde' is the past tense verb.

347 hoors: not in Hg in this sense. Corpus 61 has "hoors" at TC 4.1147.

348 goynge: not in $\mathrm{Hg}$, but cf., e.g., 'comynge.'

351 hert: $7 \times$ vs. $285 \times$ for 'herte,' but the former is "hart," the latter "heart."

The result of the re-spelling at this second stage is a virtual copy-text, bearing the substantive readings of what we suppose the archetype of the surviving manuscript versions to have been but spelled using the system of the Hengwrt manuscript (with a very few words from the Corpus Troilus, from Ellesmere, and from the Book of the Duchess tradition itself). Thus, it is certainly a text of the Book of the Duchess that never existed in the Middle Ages, but it is palpably closer to the language of Chaucer than the Tanner text and even, despite the greater incidence of identity between Fairfax spellings of common words and the Hengwrt spellings, than Fairfax. In quite a few cases, the mere application of Chaucer's English as reflected in the Hengwrt manuscript is enough to bring metrical clarity to lines that are unmetrical in Fairfax and Tanner. In a number of further cases, choosing one of two metrically variant forms of a word that Chaucer used to metrical effect in the Canterbury Tales can clarify the metre, although we are scrupulous to leave such choices to a later stage.

While the method of reaching this stage of reconstruction of the text is completely different from that recommended by Greg, the circumstances are also different. Greg's prescriptions were largely based on the situation of texts that existed in a sequence of printed editions which might differ in their accidentals primarily through modernization, but in at least one late printing of which authorial intervention could be detected. The earliest member of the sequence might then be presumed to be closest to authorial original spelling and used as copy-text. In the case of the Book of the Duchess, no early texts, good or bad, survive; all of the surviving manuscripts are the result of modernization, and there is no acceptable candidate for copy-text. But there is a good, maybe even excellent source of knowledge about authorial spelling in the case of Chaucer, and our Hengwrt-spelled Book of the Duchess may therefore represent the closest that linguistic and manuscript scholarship could lead us to a copytext in the broad terms of Greg's conception: that is, a text that, while it may not 
conform in some substantive ways with the probable original, is the closest we can manage to reflecting the spelling of that probable original.

The third stage of our process is emendation, for which we invoke two criteria: sense and metre. The theory that Chaucer's versification was charmingly rustic and irregular, resembling that of the Middle English romances, in his earlier works and became gradually more polished until he displayed his full command of metre in the Canterbury Tales is based, in our view, almost entirely on a romantic conception of genius, on the one hand, and on the poor state of the manuscripts, on the other. Chaucer was educated in a poetic tradition that offered many examples of sophisticated deployment of octosyllabic verse, and there is no strong reason to suppose that he would not have used tetrameter with confidence at the same period when he was most concerned to imitate predecessors like Machaut and Froissart closely as to content. So one starting assumption is that the Book of the Duchess was written in iambic tetrameter throughout, with only those liberties, such as an inverted first foot, omission of the first weakly stressed syllable, use of feminine rhymes, and occasional filling of a dip with two weak syllables, which Chaucer used in his pentameter verse.

The second assumption is that the poem made sense throughout. This may seem elementary, but it is striking how many passages there are in the Book of the Duchess which cry out for explanation but which all of the editors have shied away from and simply printed in silence. In addition, there are a number of passages that have attracted ingenious but strained explanations from editors. In both of these kinds of cases, we are taking the liberty of considering the possibility that the Chaucer of the 1370 s was as capable as the Chaucer of a couple of decades later of producing consistently meaningful, even witty verse using comprehensible Middle English. These two presumptions, of metricality and continuous sense, are of course hypotheses, but they seem reasonable to us.

Our main constraint is our insistence on demonstrably current Middle English of the later fourteenth century, preferably that of Chaucer himself, for this poem. When the metre is suspect and the Middle English is also non-Chaucerian, we believe there to be a high likelihood that an emendation that restores metre and also returns the poem to demonstrably Chaucerian usage is justified. Our concordance is a useful resource for establishing Chaucer's usage in areas beyond spelling. Watt's Concordance programme allows us to look for one word following another, words within a certain distance, and so on, and thus to establish Chaucer's usual syntax or idiomatic usage of particular words and phrases with some accuracy and on the fly. So if the 
reconstructed archetype of the Book of the Duchess has "I am but deed" but our database of Chaucerian usage never shows the sequence "I am but" and always shows the sequence "I nam but," we think there is a strong reason to emend the archetype.

We are also informed by a knowledge of what the typical interventions of scribes in their copy were, since this is a field which is well documented by Kane and Donaldson in a contribution of a value independent of the fortunes of their Piers Plowman editions. ${ }^{27}$ We observe instances in the text of the Book of the Duchess of scribal tendencies towards participation in the text being copied, towards explicit statement as opposed to implication, towards homogenization of syntax and sense. When apparent instances of such scribal tendencies coincide with broken metre or inadequate sense, we also feel justified in emending.

The appropriate canvas for a full demonstration of our method is of course the completed edition, ${ }^{28}$ but it may not be out of place here to give some examples of the application of the various constraints and considerations just mentioned. In what follows, currently proposed readings in the McGillivray and Seymour edition in its tentative draft (designated ' $M \& S$ ') are contrasted with the readings of the Benson edition in the Riverside Chaucer (designated 'B'), which is based closely on Fairfax.

I begin with some emendations prompted primarily by metre, although scribal diffuseness of expression and the scribal thirst for explicit statement and repetitive rather than varied expression are also in evidence. In the first example below, a series of scribal expansions in the interest of smoothing out variety have been fostered by partial repetitions already present in the text, so that, for example, the word "kyng" in "kyng Priamus," which is metrically useful, has been repeated in "kyng Lamedon," where it contributes only to spoiling the metre:

Was in the glasynge ywroght thus, Of Ector and of kyng Priamus, Of Achilles and of kyng Lamedon,
Was in the glasing ywroght thus, Of Ector and kyng Priamus Of Achilles and Lamedon

27 Kane and Donaldson, eds., Piers Plowman: The B Version, 128-213, which depends upon Kane, ed., Piers Plowman: The A Version, 115-146. See also Cowen and Kane, eds., Geoffrey Chaucer: The Legend of Good Women, 43-111.

28 A trial version of our edition including the text of the poem we developed collaboratively using the process described in this article and with introductory material and notes by M. C. Seymour has been informally self-published in pamphlet form as Part 1 of "The Pinkhurst Edition of Chaucer" and can be obtained at modest cost on request by writing to Michael Seymour, Hales Croft, Mill End, Kidlington, OX5 2EG. 
And eke of Medea and of Jason, Of Paris, Eleyne, and of Lavyne.

(B 327-31)
And eek Medea and Iason

Of Parys, Eleyne and Lauyne.

(M\&S 327-31)

Similarly, a scribal fondness for specific and explicit statement is evident in the following example: without the addition of "quene," the potentially ambiguous grammar, possibly misunderstood by the scribe, allows for the possibility that Alcione is a goddess. A similar inclination to firmly separate the human from the divine prompts the concurrent specificity of "god Morpheus":

this shal he have

(Yf I wiste where were hys cave), Yf he kan make me slepe sone, As did the goddesse quene Alcione. And thus this ylke god, Morpheus, May wynne of me moo feës thus

(B 261-66) this shal he haue, If I wiste where were his caue, If he can make me sleepe soone As dide the goddesse Alcione. And thus this ilke Morpheus May wynne of me mo fees thus

(M\&S 261-66)

Again, in the lines below, a thirst for the most explicit statement possible combines with metrical uncertainty:

She was as good, so have I reste, As ever was Penelopee of Grece

(B 1080-82)
She was as good, so haue I reste, As was Penelopee of Grece.

(M\&S 1080-82)

In all of these cases, scribal uncertainty about metre, no doubt occasioned by the loss of final $-e$, has authorized scribal interference that follows known motives; but not all interference that disrupts metre has such identifiable motives.

The almost random addition throughout of monosyllables of small or no grammatical use, frequently with the effect of flattening expression by removing variety, has also disturbed the metre. Within any dozen lines, examples such as the following are found:

For there nys planete in firmament,

$\mathrm{Ne}$ in ayr ne in erthe noon element

(B 693-94)

That they ne yive me a yifte echone (B 695)
For ther nys planete in firmament

$\mathrm{Ne}$ in eyr ne erthe non element

(M\&S 693-94)

That they ne yeue a yifte echon

(M\&S 695) 
And how I have lost suffisance, And therto I have no plesance

(B 703-4)
And how I haue lost suffisance

And therto haue no plesance,

(M\&S 703-4)

And whan al this falleth in my thoght Whan al this falleth in my thoght (B 706)

$(\mathrm{M} \& S$ 706)

The poem revealed by removing these artefacts of transmission is tighter and of more persuasive artistry than the version students and scholars have been reading in the standard editions and is, we believe, more representative of the original work.

In other cases, sense is apparently deficient in the transmitted Book of the Duchess even if the metre is not, though few of these instances have attracted the attention of editors. The dreamer tells the Man in Black,

Have som pitee on your nature

That formed yow to creature.

(B 715-16)
Haue som pitee vpon Nature

That formed yow to creature.

(M\&S 715-16)

That the Man in Black's own nature should have "formed [him] to creature" is a concept that does not bear close scrutiny, though editors have failed to remark on its oddity; rather, this may be an undetected allusion to the mourning goddess Natura of De planctu Naturae. In the Man in Black's praise of White, the transmitted text, undisturbed by the editors, leaves open the possibility that White frequently inflicted minor harm on man and woman with her tongue, surely a wrong note in a panegyric of this kind:

$\begin{array}{ll}\text { That ther was never yet throgh hir tonge } & \text { That ther was neuere thurgh hir tonge } \\ \text { Man ne woman gretly harmed } & \text { Man ne woman greued ne harmed }\end{array}$ (B 930-31)

(M\&S 930-31)

Again, an oath of romantic fidelity that explicitly leaves its swearer at full liberty to have erotic dreams about other women is so fundamentally unchivalrous as to be entirely unlikely in the mouth of an idealized lover like the Man in Black:

And never to false yow, but I mete, I nyl, as wys God helpe me soo!

(B 1233-34)
And neuere to falsen yow I hete I nyl as wys god help me so.

(M\&S 1233-34)

Editors have perhaps felt so uneasy about the sense of such dubious passages, and so without recourse because the manuscripts agree, that they have preferred to pass over them in silence, though such a tactic does not do great justice to the author. 
Sometimes a passage has attracted considerable commentary without ever being satisfactorily elucidated, as in the case of the mysterious reference to Pan:

For he had wel nygh lost hys mynde,

Thogh Pan, that men clepeth god of kynde,

Were for hys sorwes never so wroth.

(B 511-13)

Here, editors' footnotes provide a fund of information about Pan as God of Nature but indicate only editorial puzzlement and competing theories, none of them at all convincing, about why Pan should be "never so wroth" (whatever the local meaning of that word) about the Man in Black's sorrows. But perhaps the passage has been completely botched in transmission:

For he hadde wel neigh lost his mynde, That Pan that men clepe god of kynde Was for his Syrins neuer so wroth.

(M\&S 511-13)

A reference to the well known story of Pan and Syrinx (here in the spelling of the Ovide moralisé), quite resonant in the context, may lie behind the transmitted text, whose obscurity here as elsewhere, if it results from scribal incomprehension (here perhaps of a word the scribe read as "syruis" or "syrius" through minim confusion and ignorance of Ovid), may respond better to editorial scrutiny than it has to the annotator's erudition.

In a number of instances, careful consideration of metre helps to reveal oddities of expression that might otherwise be (and often have been) overlooked or made the objects of strained interpretation. Here one striking example will suffice:

And telleth me eke what ye have lore, I herde yow telle herebefore."

"Yee!" seyde he, "thow nost what thow menest;

I have lost more than thou wenest."

"What los ys that?" quod I thoo.

This passage is widely acknowledged by literary critics to be a very odd exchange indeed, though different explanations have been brought to bear, ranging from the dreamer's tact to his impenetrable stupidity, but the complete impossibility of reconciling line 1137 with the iambic tetrameter pattern should probably alert us to the 
possibility that 'lower' criticism might bring as much light in this case. It is my contention that the dreamer is neither deaf nor completely stupid, the Man in Black not exasperated at all (as his exclamation "Yee!" would suggest ${ }^{29}$ ) and not doggedly repetitive:

And telleth me eek what ye haue lore.

I herde you telle herbefore,

Ye seyde, 'Thow nost what thow menest,

I haue lost moore than thow wenest.'

What los is that?" quod I tho.

(M\&S 1135-39)

In our (draft) edited text, the dreamer, rather than being the recipient of the Man in Black's scornful repetition of his previous words, reminds the Man in Black of those words, repeating them verbatim and now enquiring as to their meaning. An explanation for this scribal alteration of the text in terms of the usual procedures and proclivities of scribes is simple and obvious: misinterpreting the line-initial word " $y e$ " as the interjection rather than the pronoun, a scribe has felt obliged to supply a subject for the verb, and in doing so has introduced an additional (repetitive) short speech by the Man in Black where one does not belong. To suggest what changes this modest emendation, if accepted, might ring on the critical picture established thus far of the relations between the two men would be a speculation beyond the bounds of the present article. Our hope is that in this and other analogous cases our work will clarify rather than simply manipulate or distort the text of the Book of the Duchess, which we hope will be revealed as a work of more grace and artistry than previous editions, based so closely on late defective manuscripts, have made it appear.

I write at a stage when our work is not quite concluded yet. Nevertheless, my claim is that our project is more than an interesting experiment, though it certainly is that. The manner of proceeding is obviously quite bold and swims against the strong recent current of anti-critical thinking, and it carries the risks and dangers associated with any new methodology. But we would claim that this is a methodology that despite its dangers and conceptual difficulties offers the likelihood of a real advance in our understanding of Chaucer's early poetry, poetry whose real nature may be obscured rather than fully revealed by the late manuscripts in which it has come down to us, and by editors who have clung to them too timidly.

University of Calgary

29 See MED s.v. ye interj., sense 1e. 


\section{Bibliography}

Benson, Larry. “Chaucer's Spelling Reconsidered." English Manuscript Studies, 1100-1700 3 (1992): 1-28.

— et al., eds. The Riverside Chaucer. 3rd ed. Boston: Houghton Mifflin, 1987.

Blake, Norman, David Burnley, Masatsugu Matsuo, and Yoshiyuki Nakao, eds. A New Concordance to the 'Canterbury Tales' Based on Blake's Text Edited from the Hengwrt Manuscript. Okoyama: Univ. Education Press, 1994.

Cerquiglini, Bernard. Éloge de la variante: Histoire critique de la philologie. Paris: Seuil, 1989. Cowen, Janet, and George Kane, eds. Geoffrey Chaucer: The Legend of Good Women. East Lansing, Mich.: Colleagues Press, 1995.

Doyle, A. I., and M. B. Parkes. "The Production of Copies of the Canterbury Tales and the Confessio Amantis in the Early Fifteenth Century." In Medieval Scribes, Manuscripts and Libraries: Essays Presented to N. R. Ker, edited by M. B. Parkes and Andrew G. Watson, 163210. London: Scolar Press, 1978.

Fisher, John H. “Animadversions on the Text of Chaucer, 1988." Speculum 63 (1988): 779-93. Greg, W. W. “The Rationale of Copy-Text.” Studies in Bibliography 3 (1950-51): 19-36.

The Hengwrt Chaucer Digital Facsimile. Ed. Estelle Stubbs. CD-ROM. Leicester, UK: Scholarly Digital Editions, 2000.

Horobin, Simon. "The Language of the Hengwrt Chaucer." In The Hengwrt Chaucer Digital Facsimile. Available at <http://www.sd-editions.com/AnaServer?HengwrtEx+0+start.anv> . Also available at $<$ http://www.canterburytalesproject.org/pubs/HGLang.html $>$.

_. "A New Approach to Chaucer's Spelling." English Studies 79 (1998): 415-24.

Kane, George, ed. Piers Plowman: The A Version. Rev. ed. London: Athlone Press, 1988.

and E. Talbot Donaldson, eds. Piers Plowman: The B Version. Rev. ed. London: Athlone Press, 1988.

McGillivray, Murray. Geoffrey Chaucer's 'Book of the Duchess': A Hypertext Edition. 2nd ed. CDROM. Calgary: University of Calgary Press, 1999.

_ . "Towards a Post-Critical Edition: Theory, Hypertext, and the Presentation of Middle English Works.” TEXT 7 (1994): 175-99.

MED. The Middle English Dictionary. Ed. Hans Kurath and Sherman M. Kuhn. Ann Arbor, Mich.: Univ. of Michigan Press, 1952-2001. Also available at $<$ http://quod.lib.umich $. \mathrm{edu} / \mathrm{m} / \mathrm{med} />$.

Mooney, Linne R. “Chaucer's Scribe.” Speculum 81 (2006): 97-138.

Robinson, F. N., ed. The Works of Geoffrey Chaucer. 2nd ed. Boston: Houghton Mifflin, 1957. Ruggiers, Paul, ed. The Canterbury Tales: A Facsimile and Transcription of the Hengwrt Manuscript, with Variants from the Ellesmere Manuscript. A Variorum Edition of the Works of Geoffrey Chaucer, vol 1. Norman: Univ. of Oklahoma Press, 1979.

Samuels, M. L. "Chaucer's Spelling." Middle English Studies Presented to Norman Davis in Honour of his Seventieth Birthday, edited by Douglas Gray and E. G. Stanley, 17-37. Oxford: Clarendon Press, 1983. 
Seymour, M. C. A Catalogue of Chaucer Manuscripts. Vol. 1, Works Before the 'Canterbury Tales.' Aldershot, UK: Scolar Press, 1995.

—. "Chaucer's Book of the Duchess: A Proposal." Medium Ævum 74 (2005): 60-70.

Thynne, William, ed. The Workes of Geffray Chaucer. London, 1532.

Watt, R. J. C. Concordance. Computer software. Available at $<\mathrm{http}: / / \mathrm{www}$.concordancesoftware .co.uk/>. 